\title{
Contributing Factors to Under-Five Child Malnutrition in Rural Bangladesh
}

\author{
Md Sazedur Rahman*, Mohammad Ali and NAM Faisal Ahmed \\ Statistics Discipline, Khulna University, Bangladesh
}

Submission: September 12, 2017; Published: September 20, 2017

*Corresponding author: Md Sazedur Rahman, Research Student, Statistics Discipline, Khulna University, Khulna-9208, Bangladesh, Email: sazedur.stat@gmail.com

\begin{abstract}
Background and objectives: Bangladesh has the highest malnutrition rates in the world. The main objective of this study is to identify and determine the main factors for child malnutrition among children under the age 5 years in rural Bangladesh.

Material and methods: This research was conducted in rural areas at Meherpur district in Bangladesh. Convenience sampling method is used and 85 under 5 child information is collected through a structured questionnaire. The information's of child's are gathered from the mothers of the child. Malnourished children is measured by using APLS method and WHO Child Growth Standard Median Index. Binary logistic regression model is used to find out the key factors of malnutrition.
\end{abstract}

Result: It is found that family income, maintain proper diet during pregnancy period, proper diet maintain for children have negative significant $(\mathrm{p}<0.05)$ effect on child malnutrition.

Conclusion: The magnitude of the child's malnutrition still is of great concern in Bangladesh. Since, poverty, imbalanced diet during pregnancy period and imbalanced diet for under 5 children influences to malnutrition are significantly associated with high prevalence of malnutrition, so government and people should reduce these factor to reduce malnutrition in rural area of Bangladesh.

Keywords: Child malnutrition; Risk factors; Children under 5; Malnutrition; Stunting; Underweight; Wasting; Public health; Under 5; Child nutrition

\section{Introduction}

WHO reported that about 5.9 million children under the age of 5 years died in 2015 and among them $45 \%$ of

all child deaths are linked to malnutrition [1]. Statistics says, about 159 million under-five children were stunned, 95 million were underweight and 50 million were wasted in 2014 [2]. Child malnutrition still remains one of the most serious public health problems in developing countries and rates of malnutrition in Bangladesh are among the highest position in the world [35]. Malnutrition is a term that is used to describe a deficiency, imbalance or excess of nutrition's, resulting in measurable adverse effects on body composition, function and clinical outcome [6]. According to UNICEF: 'People are malnourished if their diet does not provide adequate calories and protein for growth and maintenance or they are unable to fully utilize the food they eat due to illness (under nutrition). They are also malnourished if they consume too many calories (over nutrition)' [7]. Although, malnutrition refers to people who are undernourished or over nourished, it is frequently used as under nutrition. In South Asian countries, economic improvements have not been adequately reflected in improvements in child nutrition $[8,9]$. It makes the child more vulnerable to morbidity and mortality, prevents them from reaching their full physical and mental potential and growth, it also causes lower intellectual and physical abilities in adult life [10]. The problem of malnutrition in Bangladesh is much higher and this problem is almost double in Bangladesh compared to Somalia or Mozambique and equal to that of Ethiopia [11].

It is known to all that the key factor of malnutrition is extreme poverty. Poverty, hunger, malnutrition and disease are interlinked with each other. There are approximately 925 million hungry people in the world [12]. About $31.5 \%$ of the population lives below the national poverty line in Bangladesh and for every 1000 babies born, 31 die before their first birthday in Bangladesh [13]. Two-thirds of childhood death occurred because of malnutrition in Bangladesh $[14,15]$. The child's life from the time they conceived until they turn two is the most important period for foundation of the child's growth, brain and general health development. Poor fetal growth due to 
malnutrition during pregnancy results in children being both with a lower birth weight and great tendency to be stunted that means tendency to be shorter for their age group.

The absolute number of stunting children are much higher in South Asia and over $50 \%$ of South Asian children are underweight, compared to $30 \%$ in Africa [16]. From Bangladesh Demographic and Health Survey in 2014, it is shown, 36\% children under age 5 are stunted (low height for age) and 14\% are wasted low weight for height), and 33\% are under weighted (weight for age) in Bangladesh [17]. According to WHO, the level of stunting and underweight both are above the threshold 'very high' prevalence [18]. These malnourished children are at greater risk of dying, total bone growth, deficit disorder, memory deficiency, learning disabilities, impairing school performance etc [19]. It is also shown rural children are more likely to stunted, wasted and low weighted than urban children. Since, malnutrition affects physical growth, cognitive development, mortality, morbidity, physical and mental work capacity, so the main factors of child malnutrition should investigate [20-22]. Low height-for-age (stunting), low weight-for-height (wasting) and low weightfor-age (underweight) and overweight are the four indicators which measure child malnourished [8,23-25]. Generally, wasting is measured by below minus two standard deviation from median weight for height of reference population and stunting is measured by below minus two standard deviations from median height for age of reference population [26]. This study was conducted in rural area of Meherpur district in Bangladesh and the aim of this study was to identify and determine the main factors for child malnutrition among children under the age 5 years in rural Bangladesh. This study use low height-for age and low weight-for-height to identify the malnourished child.

\section{Materials and Methods}

This research was conducted in rural areas at Meherpur district in Bangladesh. Convenience sampling method was used and 85 under 5 child information is collected through a structured questionnaire. The information's of child's were gathered from the mothers of the child. The study was conducted from January 1, 2017 to March 5, 2017.

The wasting children were identified by WHO Child Growth Standard Median Index Chart [27]. The stunting children were pick out by the Advanced Pediatric Life support (APLS) method for 1-5 years child and a specific infant formula for those aged less than 1 years old. The APLS formula is: Weight $(\mathrm{kg})=($ Age $($ Years $)+4)^{*} 2$. These wasting and stunting child were defined as malnourished child as wasting and stunting are usually regarded as the best clinical indicators of children's long run health status, well-being and malnutrition $[3,28,29]$.

The Binary logistic regression model is used to find out the key factors of malnutrition. The model is as follows:
The model is: ()$=\log (1-)=0+1=0+11+\cdots+$

Where $\mathrm{Y}$ is a binary response variable, $\mathrm{Yi}=1$ if the child is malnourished and $\mathrm{Yi}=0$, if the child is not malnourished. Here $\mathrm{Xi}=$ $(\mathrm{X} 1, \mathrm{X} 2 \ldots \mathrm{Xk})$ is a set of explanatory variables and can be discrete, continuous, or a combination. Data processing and analyze have done with the help of SPSS 20.

\section{Results and Discussion}

Table 1: Binary logistic regression model.

${ }^{*} 0.05$ level of significance.

\begin{tabular}{|c|c|c|c|c|}
\hline Covariate & Coefficient & S.E. & Sig & $\begin{array}{c}\text { Odds } \\
\text { Ratio }\end{array}$ \\
\hline Family Type & -0.138 & 0.573 & 0.809 & 0.871 \\
\hline Family Income & -0.913 & 0.642 & $.035^{*}$ & 0.401 \\
\hline $\begin{array}{c}\text { Maintain proper } \\
\text { diet during } \\
\text { pregnancy } \\
\text { period }\end{array}$ & -2.569 & 0.999 & $.010^{*}$ & 0.077 \\
\hline $\begin{array}{c}\text { Mother } \\
\text { Education }\end{array}$ & -0.207 & 0.131 & 0.116 & 0.813 \\
\hline $\begin{array}{c}\text { Proper diet } \\
\text { maintain for } \\
\text { children }\end{array}$ & -2.256 & 0.739 & $.002^{*}$ & 0.105 \\
\hline Vitamin, Vaccine & -0.625 & 0.832 & 0.453 & 0.535 \\
\hline Constant & -15.28 & 0.935 & 1 & 0 \\
\hline
\end{tabular}

The demographic background and characteristics of the child's have a great influence to the malnutrition. Table 1: demonstrates that age of the child's under 1 were $31.8 \%, 1$ to under 2 years child were $21.2 \%$, and $17.6 \%, 16.5,12.9 \%$ child's aged were 2 to under 3,3 to under 4 and 4 to 5 years aged child respectively. Among them $38.8 \%$ children were malnourished and most (56.5\%) of the child's from nuclear family and $43.5 \%$ were in joint family.

It is revealed from Table 2 that there was no mothers of the child's was illiterate, the education of the maximum mothers (58.8\%) were in secondary level while the level primary (32.9\%) of mothers. The income level (5000-10000 Taka) had a highest $(43.5 \%)$ monthly income of the child's family, the income level below 5000 Taka and upper than 10000 taka had the same percent and that was $28.2 \%$.

Only $31.5 \%$ mother had maintained proper diet during pregnancy period and only $27 \%$ had maintained balanced, hygiene and nutrient diet for children. Maximum child (73\%) got treatment from the Quack. 23.8\% child got treatment from M.B.B.S doctor. A few (2.6\%) usually went to health complex and scanty amount $(.6 \%)$ used to take treatment from others sectors. Most of the mothers (66\%) used sub-sanitary latrine. $20.2 \%$ used proper sanitation, $11.7 \%$ were under non-sanitary condition and the rest $2.1 \%$ used open air (Table 2). 
Table 2: Distribution of the child based on different categories.

\begin{tabular}{|c|c|}
\hline Categories & Percent (\%) \\
\hline \multicolumn{2}{|c|}{ Age of the Child's (Years) } \\
\hline Under 1 & $31.80 \%$ \\
\hline 1 - under 2 & $21.20 \%$ \\
\hline 2- under 3 & $17.60 \%$ \\
\hline 3- under 4 & $16.50 \%$ \\
\hline \multicolumn{2}{|c|}{ Education level of mother } \\
\hline Illiterate & 0 \\
\hline Primary level & $32.90 \%$ \\
\hline Secondary level & $58.80 \%$ \\
\hline Higher Secondary level & $5.90 \%$ \\
\hline Higher Education & $2.40 \%$ \\
\hline \multicolumn{2}{|c|}{ Family Type } \\
\hline Joint & $43.50 \%$ \\
\hline Nuclear & $56.50 \%$ \\
\hline Monthly Income of family (Taka) & $4.30 \%$ \\
\hline Less than 5000 & $28.20 \%$ \\
\hline $5000-10000$ & $43.50 \%$ \\
\hline Above 10000 & $28.20 \%$ \\
\hline \multicolumn{2}{|c|}{ Nutrition } \\
\hline Malnourished & $38.80 \%$ \\
\hline Nourished & $61.20 \%$ \\
\hline \multicolumn{2}{|c|}{ Sources of Treatment } \\
\hline Quack & $73 \%$ \\
\hline Health Complex & $2.60 \%$ \\
\hline M.B.B.S. doctor & $33.80 \%$ \\
\hline Others Sanitation condition & $0.60 \%$ \\
\hline Open Air & $2.10 \%$ \\
\hline Non-Sanitary & $11.70 \%$ \\
\hline Sub-sanitary & $66.00 \%$ \\
\hline Sanitary & $20.20 \%$ \\
\hline
\end{tabular}

The dichotomous 'Malnourishment' (Yes=1, No=0) variable is defined as dependent variable and family type, family income, maintain proper diet during pregnancy period, mother education, and proper diet maintain for children and vitamin and vaccine taken are defined as independent variable.

Findings of logistic model are presented in Table 1, showing the beta coefficients, odds and significance level of each factor. It was found that family income, maintain proper diet during pregnancy period, s proper diet maintain for children had negative significant $(p<0.05)$ effect on child malnutrition, while family type, mother education, maintain vitamin and vaccine were found to be insignificant $(p>0.05)$ but have negative effect on child malnutrition.

It is observed that family income negatively affect in malnourished of children with regression coefficient -.913 and odds ratio .401 . Its entails that when family income is lower, then it's more likely to child malnourished. The prevalence of malnutrition children decreases significantly as family income increases.

Results demonstrates that maintain proper diet on pregnancy period also negatively significant to malnourished child. If mother don't maintain proper diet on pregnancy period then its positive indicator to child malnutrition. Similarly, proper diet maintain for children have also negative significant effect on child malnutrition. It means, if do not maintain of proper diet for children that affects to child malnutrition (Table 2).

\section{Conclusion}

Malnutrition and its impact on children health in Bangladesh is still a burning issue and great concern especially in case of the rural area children. Because children of the rural area are deprived and disadvantages group in the correct of the society of Bangladesh. The factors: poverty, imbalanced diet during pregnancy period and imbalanced diet for under 5 children are found to be significantly associated with the high prevalence to influence of malnutrition among rural children. Based on the above finding the recommendation can be made that government, non-governmental organizations, and the community are essential to continue and improve the poverty reduce program as well as effective nutritional awareness program should be designed and continue to reduce child malnutrition in rural Bangladesh. Malnutrition among women is also extremely prevalent in Bangladesh and more than $50 \%$ of women suffer from chronic energy deficiency [30]. This study also suggest that mother others should maintain proper diet during pregnancy period as a healthy mother can birth to a healthy child. Mother should have

also proper knowledge about proper nutritional diet of children and should maintain it to gift a child malnutrition free rural Bangladesh.

\section{References}

1. http://www.who.int/mediacentre/factsheets/fs178/en/

2. UNICEF/WHO/World Bank. Joint Child Malnutrition Estimates by UNICEF, WHO \& World Bank. 2017

3. Onis de M, Frongillo EA, Blössner M (2000) Is malnutrition declining? An analysis of changes in levels of child malnutrition since 1980. Bulletin of the World Health Organization 78(10): 1222-1233.

4. Das S, Rahman RM (2011) Application of ordinal logistic regression analysis in determining risk factors of child malnutrition in Bangladesh. Nutr J 10: 124.

5. https://www.savethechildren.org.uk/sites/default/files/images/ Malnutrition_in_Bangladesh.pdf

6. Saunders J, Smith T, Stroud M (2011) Malnutrition and undernutrition. Medicine 39(1): 45-50.

7. https://www.unicef.org/progressforchildren/2006n4/ malnutritiondefinition.htm

8. IAdnan MSF, Khan MWR (2015) Determinants of malnutrition among urban slum children in Bangladesh. Health economics review 5: 22. 
9. Gupta MD (2010) Death clustering, mothers' education and the determinants of child mortality in rural Punjab, India. Population studies $44(3):$ 489-505.

10. Robert BE, Morris SS, Jennifer B (2003) Where and why are 10 million children dying every year? The lancet 361(9376): 2226-2234.

11. Md Siddiqi NA, Md Haque N, Md Goni A (2011) Malnutrition of underfive children: evidence from Bangladesh. Asian Journal of Medical Sciences 2(2): 113-119.

12. John H, Rosegrant M, Torero M (2012) Hunger and malnutrition. p. 68.

13. https://www.adb.org/countries/bangladesh/poverty

14. Pelletier DL, Frongillo EA, Schroeder DG, Habicht JP (1995) The effects of malnutrition on child mortality in developing countries. Bull World Health Organ 73(4): 443-448.

15. Ahmed T, Hossain M, Sanin KI (2012) Global burden of maternal and child undernutrition and micronutrient deficiencies. Ann Nutr Metab (61 Suppl 1): 8-17.

16. Vulimiri R, Jonsson U, Rohde J (1997) Malnutrition: a South Asianenigma. pp. 11-22.

17. https://dhsprogram.com/pubs/pdf/FR311/FR311.pdf

18. http://www.who.int/childgrowth/publications/physical_status/en/

19. Martorell R, Ho TJ (1984) Malnutrition, morbidity, and mortality Population and Development Review 10 Suppl: 49-68.

20. Nnyepi M, Bandeke T, Mahgoub SEO (2006) Factors affecting prevalence of malnutrition among children under three years of age in Botswana. African Journal of Food, Agriculture, Nutrition and Development 6(1).

This work is licensed under Creative Commons Attribution 4.0 Licens

DOI: $10.19080 / J O J C S .2017 .04 .555633$
21. Pelletier DL, Frongillo EA (2003) Changes in child survival are strongly associated with changes in malnutrition in developing countries. J Nutr 133(1): 107-119.

22. Smith LC, Lawrence JH (2000) Explaining child malnutrition in developing countries: A cross-country analysis. Intl Food Policy Res Inst 111: 1-2.

23. Peter L, Martin R (1995) Poverty and household size. The economic journal 105(433): 1415-1434.

24. http://www.who.int/nutgrowthdb/about/introduction/en/index2. html

25. Bantamen G, Belaynew W, Dube J (2014) Assessment of factors associated with malnutrition among under five years age children at Machakel Woreda, Northwest Ethiopia: a case control study. J Nutr Food Sci 4(1): 256.

26. https://www.unicef.org/infobycountry/stats_popup2.html

27. http://motherchildnutrition.org/malnutrition-management/info/ mcno-weight-for-height-length.pdf

28. Heltberg R (2009) Malnutrition, poverty, and economic growth. Health Econ (18 Suppl 1): S77-S88.

29. Shrimpton R (2002) Nutrition in communities. Nutrition: a foundation for development. ACN/SCN and IFPRI: Geneva.

30.http://www.fao.org/ag/agn/nutrition/bgd_en.stm

\section{Your next submission with Juniper Publishers will reach you the below assets}

- Quality Editorial service

- Swift Peer Review

- Reprints availability

- E-prints Service

- Manuscript Podcast for convenient understanding

- Global attainment for your research

- Manuscript accessibility in different formats

( Pdf, E-pub, Full Text, Audio)

- Unceasing customer service

Track the below URL for one-step submission

https://juniperpublishers.com/online-submission.php 